\title{
Association between different types of plant-based diets and leptin levels in healthy volunteers
}

\author{
Patrycja Gogga ${ }^{1}$, Aleksandra Śliwińska ${ }^{2} \square$, Ewa Aleksandrowicz-Wrona² and Sylwia \\ Małgorzewicz ${ }^{2}$
}

'Department of Nutritional Biochemistry, Faculty of Health Sciences, Medical University of Gdańsk, Gdańsk, Poland; ${ }^{2}$ Department of Clinical Nutrition and Dietetics, Faculty of Health Sciences, Medical University of Gdańsk, Gdańsk, Poland

Leptin is an important factor regulating appetite and energety metabolism; disturbances in its signaling are related to adiposity and contribute to the excessive body fat. About a third of the human population is overweight or suffers from obesity, as well as from associated medical conditions. It is well established that vegetarian, especially vegan, diet is very effective in lowering BMI and body fat, thus, plant-based diets are associated with a lower risk of obesity. The aim of this study was to evaluate the plasma levels of leptin in lacto-ovo-vegetarian and vegan volunteers with normal BMI. The intake of energy and selected diet components such as polyunsaturated fatty acids (PUFA) and carbohydrates was also investigated. The study involved healthy women - 14 omnivores, 17 lacto-ovo-vegetarians, and 11 vegans. All women had a normal BMI (18.5-24.99). The plasma leptin levels were examined with immunoenzymatic test (ELISA). All participants were interviewed to estimate their nutrient intake by performing a 24-hour dietary recall. Both lacto-ovo-vegetarians and vegans had lower plasma leptin concentrations than their meat-consuming counterparts. Every analyzed diet group had a different body fat content, with the highest level in omnivores and the lowest in vegans. All participants had similar calorie, total fat, and total carbohydrates intake. Total PUFA and specifically omega- 3 fatty acids consumption was lower in omnivores when compared to both types of plant diet; the same was found for fiber intake. Our results suggest that adopting a plant-based diet may be beneficial for energetic metabolism, as it significantly lowers the body fat storage and circulating leptin levels.

Key words: leptin, vegetarian, vegan, obesity, omega-3

Received: 29 October, 2018; revised: 04 February, 2019; accepted: 11 February, 2019; available on-line: 15 February, 2019

$\checkmark$ e-mail: aleksandrasliw@wp.p

Abbreviations: AgRP, agouti-related protein; BMI, body mass index; FA, fatty acids; LDL, low-density lipoprotein; NPY, neuropeptide Y; POMC, proopiomelanocortin; PUFA, poly-unsaturated fatty acids; SFA, saturated acids; TAG, triacylglycerols

Acknowledgements of Financial Support: The study was a part of the Nutritional Status of Vegetarians Research, financed by Medical University of Gdańsk, (grant no: MN 01-0098/08).

\section{INTRODUCTION}

Leptin is a peptide hormone synthesized mainly in the white adipose tissue with smaller amounts secreted by the other organs, including brain, stomach, and placenta, that plays a pleiotropic role in the body. This adipokine acts as a regulator of energy homeostasis. It decreases food consumption, thus contributing to the maintenance of the normal body mass (Gogga et al., 2011; Friedman, 2014). There are several leptin receptors, yet the most important isoform is the long isoform, LEPRb, a membrane receptor expressed in the hypothalamus and numerous peripheral tissues, comprising gastrointestinal tract and related organs, pancreas, gonads, kidneys, spleen, lungs, and muscles (including heart muscle) (Margetic et al., 2002). By binding to its hypothalamic receptors leptin activates signaling pathway that decreases the gene expression of neuropeptide Y (NPY) and agoutirelated protein $(\mathrm{AgRP})$, while concomitantly increasing the expression of gene encoding proopiomelanocortin (POMC); these changes elicit decrease of appetite and food consumption leading to the loss of body fat and body mass (Belgardt \& Brüning, 2010).

Apart from controlling the appetite, leptin is deeply involved in lipid metabolism. It stimulates the increase in expression of genes encoding enzymes involved in lipolysis and $\beta$-oxidation in numerous tissues, such as WAT (William et al., 2002), liver (Toyoshima et al., 2005), pancreatic islands (Shimabukuro et al., 1997), skeletal muscles (Akasaka et al., 2009), and heart (Sharma et al., 2009). On the other hand, leptin decreases lipogenic enzymes expression and de novo fatty acids (FA) biosynthesis (William et al., 2002). Additionally, it suppresses free FA intake by adipose tissue cells, thus decreasing their bioavailability for TAG synthesis (Buettner et al., 2008). Leptin is also involved in lipid metabolism of bile gland - under the influence of high-fat diet, it stimulates the disposal of excess cholesterol with bile (VanPatten et al., 2001).

Leptin also participates in the carbohydrate metabolism. It is well known that this adipokine increases insulin sensitivity in the peripheral tissues. It stimulates glucose uptake in skeletal muscle cells, leading to the increase in glycogen storage in myocytes. In hepatocytes, leptin decreases glucose intake resulting in a decrease in glycogen synthesis in these cells, together with decreased gluconeogenesis. Moreover, it decreases both the basic and glucose-stimulated secretion of insulin from the pancreatic islands (Morton \& Schwartz, 2011).

In general, leptin is an adipokine deeply involved in appetite regulation and energy metabolism. Disturbances in its functioning lead to various metabolic disorders, which may be elicited by the lack of Lep gene product (Montague et al., 1997) or by so-called leptin resistance. The cause of leptin resistance may be a mutation in the gene encoding the long form of leptin receptor (Chen et al., 1996). It may also be a result of the decreased efficiency of leptin transport through the blood-brain barrier (Caro et al., 1996) or by disturbances in leptin signaling pathway (El-Haschimi et 
al., 2000). The two latter dysfunctions result from the high-fat diet (El-Haschimi et al., 2000). Leptin resistance may lead to adiposity, which is one of the most common health issues in the modern world, posing an important and urgent challenge for medicine (Rössner, 2002). People with excess body fat have a lower quality of life when compared to the normal-weight subjects, but, what is more relevant, they are vulnerable to a number of additional negative health outcomes (Mottillo et al., 2010). Moreover, central obesity is a component of the metabolic syndrome, a cluster of metabolic disorders including insulin resistance, dyslipidaemia, and elevated blood pressure (Alberti et al., 2006), which contributes to the development of multiple cardiovascular diseases and type 2 diabetes.

A diet excluding meat appears to be useful in the prevention of cardiovascular diseases, type 2 diabetes, and obesity. Vegetarians have significantly lower levels of triacylglycerols, total cholesterol, low-density lipoprotein (LDL), glucose, blood pressure, waist circumference, and body mass index (BMI) when compared to omnivores (Rizzo et al., 2011). One can assume that vegetarians, having lower BMI than meatconsumers, are characterized by lower leptin levels. Despite many reports suggesting that the vegetarian diet may protect against particular diseases, its influence on the energy metabolism is poorly understood. The research on the levels of circulating leptin in vegetarians pertain mainly to children (Ambroszkiewicz et al., 2004) or specific ethnic groups, whose diet is determined by the environmental conditions (Winnicki et al., 2002); there is little research regarding this issue conducted on adult men and women living in the developed countries (Kahleova et al., 2011). It is well established that a high-calorie diet, rich in SFAs and sugar, and fiber-poor is a crucial factor in the development of obesity. The vegetarian diet is rich in dietary fiber and has low caloric density, which might reduce the amount of stored fat and thus levels of circulating leptin. Results of the recent studies indeed suggest that vegetarian diet patterns may contribute to the lower body mass (Huang et al., 2016).

\section{OBJECTIVE}

This paper was aimed to examine plasma leptin levels in healthy volunteers with normal BMI being on lactoovo-vegetarian or vegan diet, and to analyze the possible correlation between these levels and selected diet components.

\section{MATERIAL AND METHODS}

Subjects. The study involved healthy women $(\mathrm{N}=42)$ between 18 and 53 years old (mean age was 29.5 \pm 8.2). Participants were divided into three groups. There were 14 omnivores, 17 lacto-ovo-vegetarians, and 11 vegans. All women had normal BMI, i.e. between 18.5 and 25.0. The participants were recruited via electronic media. The announcements about the research, including detailed information on the purpose and planned course of the study, were released on particular websites, providing instructions on how to join in. To be included in the study group the participants were required to had been on a vegetarian or vegan diet for at least one year continuously. The control group consisted of persons who consume meat regularly.
None of the diet groups included any individuals with any chronic diseases nor pregnant or lactating women. All subjects participated voluntarily and provided fully informed consent before the study began. During consultations with the dietician venous blood was collected after an overnight fast. The study was approved by the local Independent Bioethics Commission for Research and was a part of the Nutritional Status of Vegetarians Research (grant no: MN 010098/08). To estimate participants' nutrient intake a 24-hour dietary recalls were performed (GronowskaSenger, 2013). Respondents were not informed about the interview prior to the consultation, in order to avoid potential changes in eating habits. All recalls were performed by a well-trained, experienced interviewer, using an album with photographs of various food products and meals to help the respondents estimate the portion sizes. On the basis of the interviews, the intake of energy and selected diet components was calculated, using Cronometer ${ }^{\circledR}$ (https://cronometer.com/). This software enables the user to analyze single meals and beverages and estimate their nutritional values.

Following anthropometric data were collected:

- height, using the measuring rod;

- circumference of waist, hip, and arm, with a tape measure;

- body mass, with an electronic scale;

- percentage of body fat content, using the multi-frequency bioelectrical impedance analyzer Bodystat 1500 .

Height and body mass were used to calculate Body Mass Index.

Analytical methods. The collected blood was immediately centrifuged to obtain plasma, which was stored at $-80^{\circ} \mathrm{C}$ before the analysis. Plasma leptin levels were assessed with immunoenzymatic test ELISA (DRG Diagnostics, Germany) and ELISA plate reader (ELIZAMAT 3000).

Statistical analyses. All calculations (descriptive statistics, tests, diagrams) were made in Statistica 12 (Statsoft). When the required assumptions were met, one-way ANOVA test was used. The test applied post-hoc was the Tukey's test. Due to the lack of variance homogeneity, presumable differences in total fat and omega-3 FA intake were evaluated with the Kruskal-Wallis test. The Dunn's test was applied post-hoc. Outlier values were excluded based on the Grubb's test result. The results were regarded as statistically significant when $p \leq 0.05$. All statistically significant results were presented using boxplots.

\section{RESULTS}

\section{Plasma leptin levels}

Mean concentration of leptin in the plasma was $7.45 \pm 2.75$ for omnivores, and $3.87 \pm 1.96$ and $2.89 \pm 1.89$

Table 1. Mean plasma leptin levels $[\mathrm{ng} / \mathrm{ml}]$ in women from different diet groups.

\begin{tabular}{lcccc}
\hline Diet type & Mean \pm S.D. & Min & Max & $\mathrm{N}$ \\
\hline Omnivore & $7.45 \pm 2.75$ & 1.0 & 11.6 & 14 \\
\hdashline Vegetarian & $3.87 \pm 1.96$ & 0.6 & 8.5 & 17 \\
\hdashline Vegan & $2.89 \pm 1.89$ & 0.6 & 7.2 & 11 \\
\hline
\end{tabular}



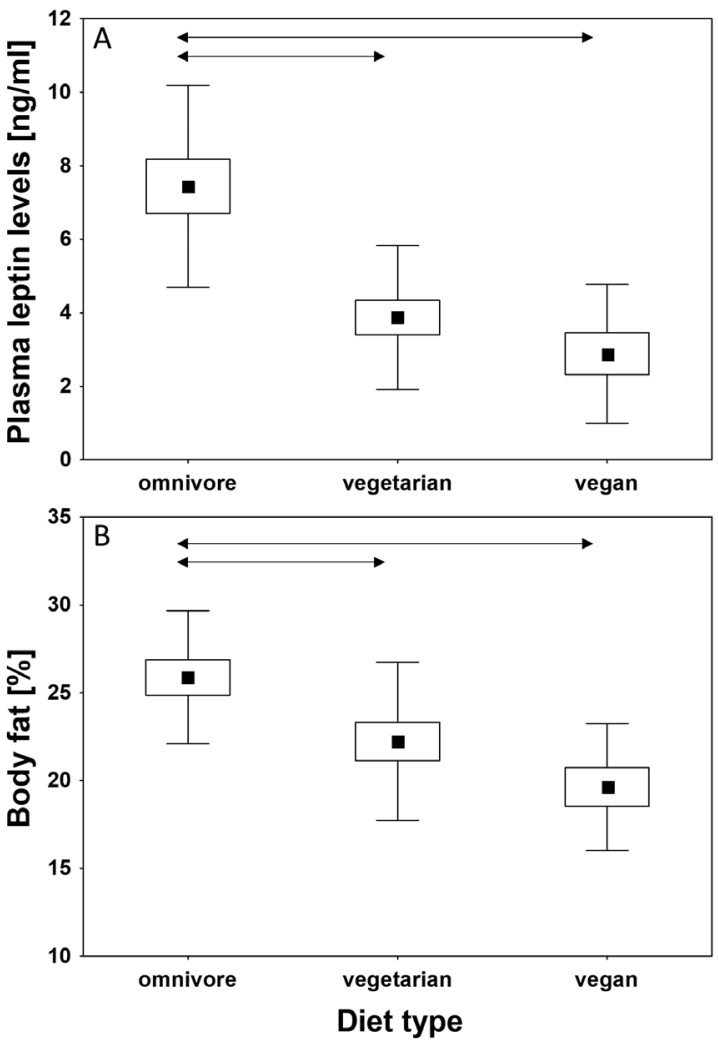

Figure 1. Plasma leptin levels (A) and percentage body fat (B) in women from different diet groups.

Center point - mean, box - standard error, whiskers - standard deviation. Arrows indicate statistically significant differences between the groups according to the Tukey's post-hoc test at $p=0.0001(\mathbf{A})$ and $p=0.002$ (B).

for vegetarians and vegans, respectively (Table 1). There were statistically significant differences in plasma leptin levels between different diet groups $\left(\mathrm{F}_{239}=15.244\right.$ $p=0.0001)$ (Fig. 1A). The Tukey's test revealed that leptin concentrations were significantly lower in both vegetarians and vegans when compared to omnivores.

\section{Anthropometry}

There were statistically significant differences in body fat percentage $\left(\mathrm{F}_{2.39}=7.536, p=0.002\right)$ (Fig. 1B) between omnivores and both plant-based diet groups, thus despite the fact that BMI was normal in all participants, they varied in body fat content, which was higher in meat-eaters.

\section{Dietary components intake}

The calorie $\left(\mathrm{F}_{2.35}=0.151, p=0.860\right)$ and total fat $\left(\mathrm{H}_{2.36}=0.541, p=0.763\right)$ intake did not differ significantly between the examined diet groups. In contrast, total PUFA $\left(\mathrm{F}_{2.35}=9.691, p=0.0004\right)$ and omega-3 FA $\left(\mathrm{H}_{2.36}=15.530, p=0.0004\right)$ intake was significantly different in the analyzed groups. Post-hoc tests revealed that daily intake of PUFA was lower in omnivores when compared to both types of the vegetarian diet, while omega-3 FA intake was higher in vegans in comparison to the other groups. The same was found for fiber intake $\left(\mathrm{F}_{2.36}=8.233, p=0.001\right)$, which was higher in vegans than in the other diet types, though there were no statistically significant differences in total carbohydrate intake $\left(\mathrm{F}_{2.35}=1.055, p=0.359\right)$ (Table 2, Fig. 2).
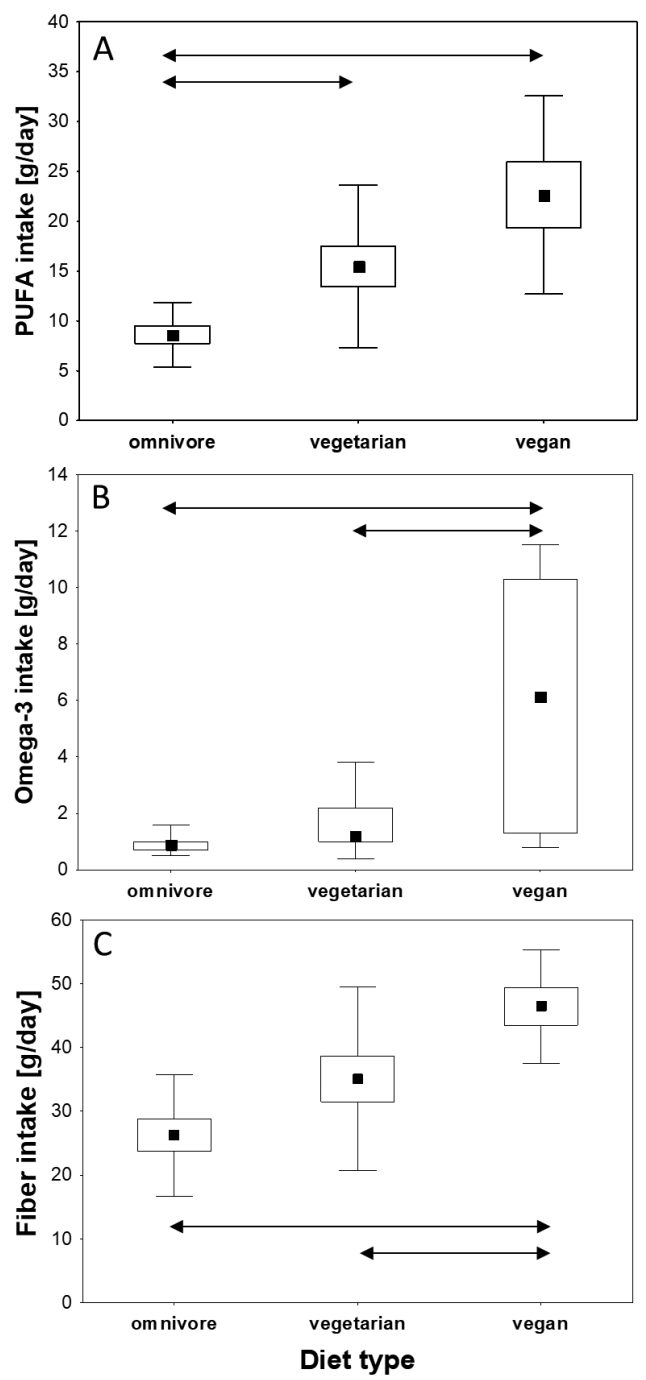

Figure 2. Daily intake of PUFA (A), omega-3 FAs (B), and fiber (C) by women from different diet groups.

(A, C) center point - mean, box - standard error, whiskers standard deviation; (B) center point - median, box - first and third quartile, whiskers - range. Arrows indicate statistically significant differences between the groups according to the Tukey's post-hoc test at $p<0.001(\mathbf{A})$ and $p=0.001(\mathbf{C})$, and Dunn's test at $p<0.001$ (B).

Table 2. Results of analysis of variation for selected dietary components consumed by women from different diet groups. The daily intake of calories, PUFA, total carbohydrates and fiber was analyzed using parametric ANOVA.

\begin{tabular}{lllll}
\hline \multirow{2}{*}{ Daily intake } & \multicolumn{2}{l}{ Test result } & $\mathrm{N}$ & $\mathrm{N}$ \\
\cline { 2 - 5 } & $\mathrm{F}$ & $\mathrm{H}$ & & \\
\hline Calories & 0.151 & & 0.860 & 38 \\
\hline Total fat & & 0.541 & 0.763 & 39 \\
\hline PUFA & 9.691 & & $<0.001$ & 38 \\
\hline Omega-3 & & 15.530 & $<0.001$ & 39 \\
\hline Total carbohydrates & 1.055 & & 0.359 & 38 \\
\hdashline Fiber & 8.233 & 0.001 & 39 \\
\hline
\end{tabular}




\section{DISCUSSION}

The results of the presented study showed that people who adopted a vegetarian dietary pattern had lower plasma levels of leptin when compared to the meat-consumers. Similar results were obtained by Ambroszkiewicz and colleagues (Ambroszkiewicz et al., 2004). That study, however, pertained to prepubertal children. The mean plasma level of the adipokine in vegetarian children was $3.0 \pm 1.1 \mathrm{ng} / \mathrm{ml}$. The studied group was mixed and consisted mainly of lacto-ovo-vegetarians, with smaller share of ovo-vegetarians and only a few vegans. For children who consumed meat it was $5.1 \pm 2.0 \mathrm{ng} / \mathrm{ml}$. In a later study of the same authors the vegetarian children had leptin levels at $3.0 \pm 2.1 \mathrm{ng} / \mathrm{ml}$, while in children on a traditional diet it was $6.8 \pm 3.4 \mathrm{ng} / \mathrm{ml}$ (Ambroszkiewicz et al., 2011). The presented values are comparable with the ones obtained in this study. The mean plasma leptin levels for omnivores, vegetarians and vegans were 7.45 $\mathrm{ng} / \mathrm{ml}, 3.87 \mathrm{ng} / \mathrm{ml}$, and $2.89 \mathrm{ng} / \mathrm{ml}$, respectively. Corresponding conclusions can be made also from the study performed by Kim and Bae (Kim \& Bae, 2015). The authors examined the plasma concentrations of leptin between semi-vegetarians and omnivores. Postmenopausal women being on semi-vegetarian diet had significantly lower plasma leptin concentrations than their mixeddiet counterparts. The influence of a plant diet on the plasma level of leptin was examined also in patients with diabetes type 2 , in a prospective study. The participants were assigned to one of the two groups: an experimental group, which received only plant meals for 24 weeks, and a control group, being on a conventional diabetic diet. Both diets were calorie-restricted. Additionally, all participants were prescribed an exercise program. The vegetarian diet was based almost entirely on plant foods. The only animal-derived product was a low-fat yogurt consumed once a day. At the end of the experiment, the subjects on the plant diet had significantly lower levels of plasma leptin when compared to the conventionaldiet group. This decrease may be attributed, at least partially, to the reduction in the fat tissue volume (both visceral and subcutaneous), which was more pronounced in the experimental group (Kahleova et al., 2011).

It has been long known that plasma leptin levels strongly correlate with the amount of adipose tissue, thus the more obese a person is, the higher blood leptin concentration is observed (Considine et al., 1996). Moreover, elevated leptin levels may further contribute to the weight gain because of the leptin resistance. This condition results from a high-fat diet, when there is no appetite-decreasing effect of the hormone. Therefore, high leptin concentrations may signal excessive calorie intake and be symptomatic of the development of obesity and associated disorders. It is well documented that the principal factor affecting the plasma leptin level is the amount of adipose tissue, i.e. the number and size of adipocytes, and many publications showed that vegetarians, especially vegans, are slimmer than meat-eaters (Tonstad et al., 2009; Sabaté \& Wien, 2015; Huang et al., 2012; Dinu et al., 2017). Thus, benefits from adopting a vegetarian diet manifested as lower plasma levels of the adipokine in comparison to the omnivores may be attributed to the lower average body fat content. We managed to confirm this observation in our study. Despite the fact that all included women had normal BMI, analysis of variance showed significant differences in body fat content $\left(\mathrm{F}_{2.39}=7.536, p=0.002\right)$, which was lower in both types of vegetarian-diet groups when compared to the meat-consumers.
The analysis of the frequency of consuming certain food components showed that people who adopt a plant diet exhibit higher consumption of PUFA than meatconsumers (Clarys et al., 2014). Vegan participants of our study also had significantly higher intake of omega-3 FA $(p<0.001)$ when compared to the other analyzed diet groups, while calorie and total fat intake was similar. This may be an additional factor (along with the energy storage) responsible for the observed discrepancies in plasma leptin levels. The influence of a habitual diet on plasma concentrations of the hormone, independent of body fat, was previously described (Winnicki et al., 2002). In vitro and animal experiments provided evidence that diet composition, mainly PUFA intake, is a significant factor influencing circulating levels of the adipokine because of their participation in leptin gene expression control. Observations from DIO mice fed a diet rich in omega-3 FA suggested that one of the epigenetic factors influencing the expression of leptin gene are histone modifications (Shen et al., 2014). In rats, the expression of the leptin gene in epididymal adipose tissue was lower in the group fed omega-3 FA-enriched diet when compared to the group fed lard-enriched diet (Reseland et al., 2001). In another study, rats kept on a diet rich in SFA had higher both plasma leptin level and leptin mRNA concentration in retroperitoneal adipose tissue when compared to animals fed meals rich in omega-3 FA (Ukropec et al., 2003). Moreover, these authors made an interesting discovery that including omega-3 FA in a diet may also interact with the expression of the short form of the leptin receptor gene. In examined rats, omega-3 FA up-regulated mRNA biosynthesis of this receptor in the liver, contributing to lowering of the plasma leptin level (Ukropec et al., 2003). Additionally, in vegetarian children there were higher levels of the circulating leptin receptor - a soluble isoform of the receptor, binding adipokine in the vascular system - when compared to the omnivores (Ambroszkiewicz et al., 2011). Increased expression of the genes encoding certain leptin receptors enables binding more leptin molecules, yet the regulatory mechanism of this process needs further studies.

Another explanation for the observed plasma leptin levels variation may be the differences in carbohydrates composition of diets of the examined subjects. The vegetarians and vegans who participated in our study exhibited the same intake of carbohydrates as their meat-eating counterparts, while the fiber intake was significantly higher. This suggests that participants whose diet is conventional are likely to consume more mono- and disaccharides and starch, which are known for their high glycaemic index values. Concentrations of glucose and insulin were not analyzed in the presented study, it is known, however, that strict plant diet improves both fasting and postprandial plasma glucose levels (Kim et al., 2013; Dinu et al., 2017). Additionally, a significant decrease in glycaeted hemoglobin (Hb A1c) (Barnard et al., 2009) and improved insulin sensitivity (Kahleova et al., 2011) in vegetarian subjects was previously observed in the interventional studies. Concomitantly, it was established that leptin correlates positively with insulin and glucose concentrations - the regulation of the leptin gene expression is stimulated by circulating insulin, which acts upon its transcription and translation (Lee et al., 2007; Pratley et al., 2000). Glucose is also engaged in the modulation of plasma leptin levels by participating in the upregulation of the Lep gene expression and secretion of the hormone by the adipose tissue (Mueller et al., 1998).

We are aware of the limitations of the presented study. First, the number of participants was relatively 
small. Second, for dietary assessment we used 24-hour diet recall, what may result in under- or overestimating the real food intake, making the method disputable. For the best results, it is recommended to use 24-hour diet recalls repeated for few days or dietary records, however, for evaluating mean nutrient consumption in a certain group - e.g. vegans - 24-h diet recall is an adequate tool (Gronowska-Senger, 2013). One must keep in mind that the aim of this study was to examine the average intake of given nutrients and to correlate it with the plasma leptin concentration, not to assess the exact intake at the individual level. Moreover, this method has some essential advantages. The ongoing recording may affect the type and amount of food eaten by the participants (Thompson \& Byers, 1994). There are also suggestions that actual food intake may be underreported, especially by certain groups of respondents (Goris et al., 2000; Poslusna et al., 2009). On the other hand, a 24-h diet recall does not affect one's eating habits, because the interview is conducted after food consumption. Additionally, live conversation gives the possibility to question a respondent thoroughly about the details that may be missed during the recording, e.g. consumed snacks or the way food was prepared (Thompson \& Byers, 1994).

This was a pilot study, aimed for quick preliminary results. The next stage is presently under way - in addition to 24-h recalls, respondents are making dietary records for 3 to 7 days, for more accurate information on nutrient consumption. Moreover, the study and control group sizes have been increased.

\section{CONCLUSIONS}

In conclusion, the results of the presented study showed that people whose diet is based primarily or entirely on plant food have lower plasma level of leptin when compared to omnivores, as a result of lower body fat content, which was observed in examined lactoovo-vegetarian and vegan women. An additional factor reducing leptin plasma level in those women may be the higher intake of omega-3 FA, as it was proved that diet composition, mainly fatty acid type, may influence the circulating leptin level. Through positive changes in energy metabolism, manifested in lower leptin concentrations, plant-based diets may be an important factor preventing people from developing metabolic syndrome with the associated health outcomes.

\section{Acknowledgements}

We wish to thank Kate Leighton for language correction of the manuscript.

\section{REFERENCES}

Akasaka Y, Tsunoda M, Ide T, Murakami K (2009) Chronic leptin treatment stimulates lipid oxidation in immortalized and primary mouse skeletal muscle cells. Biochim Biophys Acta 1791: 103-109. https://doi.org/10.1016/j.bbalip.2008.11.003

Alberti KG, Zimmet P, Shaw J (2006) Metabolic syndrome - a new world-wide definition. A consensus statement from the international diabetes federation. Diabet Med 23: 469-480. https://doi. org/10.1111/j.1464-5491.2006.01858.x

Ambroszkiewicz J, Klemarczyk W, Gajewska J, Chełchowska M, Rowicka G, Ołtarzewski M, Laskowska-Klita T (2011) Serum concentration of adipocytokines in prepubertal vegetarian and omnivorous children. Med Wieku Rozwoj 15: 326-334 (in Polish)

Ambroszkiewicz J, Laskowska-Klita T, Klemarczyk W (2004) Low serum leptin concentration in vegetarian prepubertal children. Rocz Akad Med Bialymst 49: 103-105 (in Polish)

Barnard ND, Cohen J, Jenkins DJ, Turner-McGrievy G, Gloede L, Green A, Ferdowsian H (2009) A low-fat vegan diet and a con- ventional diabetes diet in the treatment of type 2 diabetes: a randomized, controlled, 74-wk clinical trial. Am J Clin Nutr 89: 1588SS1596S. https://doi.org/10.3945/ajcn.2009.26736H

Belgardt BF, Brüning JC (2010) CNS leptin and insulin action in the control of energy homeostasis. Ann N Y Acad Sci 1212: 97-113. https://doi.org/10.1111/j.1749-6632.2010.05799.x

Buettner C, Muse ED, Cheng A, Chen L, Scherer T, Pocai A,Su K, Cheng B, Li X, Harvey-White J, Schwartz GJ, Kunos G, Rossetti L (2008) Leptin controls adipose tissue lipogenesis via central, STAT3independent mechanisms. Nat Med 14: 667-675. https://doi.org/ $10.1038 / \mathrm{nm} 1775$

Caro JF, Kolaczynski JW., Nyce MR, Ohannesian JP, Opentanova I, Goldman WH, Lynn RB, Zhang PL, Sinha MK, Considine RV (1996) Decreased cerebrospinal-fluid/serum leptin ratio in obesity: a possible mechanism for leptinresistance. Lancet 348: 159-161. https://doi.org/10.1016/S0140-6736(96)03173-X

Chen H, Charlat O, Tartaglia LA, Woolf EA, Weng X, Ellis SJ, Lakey ND, Culpepper J, Moore KJ, Breitbart RE, Duyk GM, Tepper RI, Morgenstern JP (1996) Evidence that the diabetes gene encodes the leptin receptor: identification of a mutation in the leptin receptor gene in $\mathrm{db} / \mathrm{db}$ mice. Cell 84: 491-495

Clarys P, Deliens T, Huybrechts I, Deriemaeker P, Vanaelst B, De Keyzer W, Hebbelinck M, Mullie P (2014) Comparison of nutritional quality of the vegan, vegetarian, semi-vegetarian, pesco-vegetarian and omnivorous diet. Nutrients 6: 1318-1332. https://doi.org/ $10.3390 /$ nu6031318

Considine RV, Sinha MK, Heiman ML, Kriauciunas A, Stephens TW, Nyce MR, Ohannesian JP, Marco CC, McKee LJ, Bauer TL, Caro JF (1996) Serum immunoreactive-leptin concentrations in normalweight and obese humans. N Engl J Med 334: 292-295. https://doi. org/10.1056/NEJM199602013340503

Dinu M, Abbate R, Gensini GF, Casini A, Sofi F (2000) Vegetarian, vegan diets and multiple health outcomes: A systematic review with meta-analysis of observational studies. Crit Rev Food Sci Nutr 57: 3640-3649. https://doi.org/10.1080/10408398.2016.1138447

El-Haschimi K, Pierroz DD, Hileman SM, Bjørbaek C, Flier JS (2000) Two defects contribute to hypothalamic leptin resistance in mice with diet-induced obesity. J Clin Invest 105: 1827-1832. https://doi. org/10.1172/JCI9842

Friedman J (2014) 20 years of leptin: leptin at 20: an overview. J Endocrinol 223: T1-T8. https://doi.org/10.1530/JOE-14-0405

Gogga P, Karbowska J, Meissner W, Kochan Z (2011) Role of leptin in the regulation of lipid and carbohydrate metabolism. Postepy Hig Med Dosw 65: 255-262 (in Polish)

Goris AH, Westerterp-Plantenga MS, Westerterp KR (2000) Undereating and underrecording of habitual food intake in obese men: selective underreporting of fat intake. Am J Clin Nutr 71: 130-134. https://doi.org/10.1093/ajcn/71.1.130

Gronowska-Senger A (2013) Characteristicsof dietary assessment methods and principles for choosing the proper one. In Methodological guide for nutrition research. Gronowska-Senger A ed, pp 5-16. Committee of Human Nutrition Science of the Polish Academy of Scienes (in Polish)

Huang RY, Huang CC, Hu FB, Chavarro JE (2016) Vegetarian diets and weight reduction: a meta-analysis of randomized controlled trials. J Gen Intern Med 31: 109-116. https://doi.org/10.1007/s11606015-3390-7

Huang T, Yang B, Zheng J, Li G, Wahlqvist ML, Li D (2012) Cardiovascular disease mortality and cancer incidence in vegetarians: a meta-analysis and systematic review. Ann Nutr Metab 60: 233-240. https://doi.org/10.1159/000337301

Kahleova H, Matoulek M, Malinska H, Oliyarnik O, Kazdova L, Neskudla T, Skoch A, Hajek M, Hill M, Kahle M, Pelikanova T (2011) Vegetarian diet improves insulin resistance and oxidative stress markers more than conventional diet in subjects with Type 2 diabetes. Diabet Med 28: 549-559. https://doi.org/10.1111/j.14645491.2010.03209.x

Kim MH, Bae YJ (2015) Comparative study of serum leptin and insulin resistance levels between Korean postmenopausal vegetarian and non-vegetarian women. Clin Nutr Res 4: 175-181. https://doi.org/ 10.7762/cnr.2015.4.3.175

Kim MS, Hwang SS, Park EJ, Bae JW (2013) Strict vegetarian diet improves the risk of factors associated with metabolic diseases by modulating gut microbiota and reducing intestinal inflammation. Environ Microbiol Rep 5: 765-775. https://doi.org/10.1111/17582229.12079

Lee MJ, Wang Y, Ricci MR, Sullivan S, Russell CD, Fried SK (2007) Acute and chronic regulation of leptin synthesis, storage, and secretion by insulin and dexamethasone in human adipose tissue. $A m J$ Physiol Endocrinol Metab 292: E858-E864. https://doi.org/10.1152/ ajpendo.00439.2006

Margetic S, Gazzola C, Pegg GG, Hill RA (2002) Leptin: a review of its peripheral actions and interactions. Int J Obes Relat Metab Disord 26: 1407-1433. https://doi.org/10.1038/sj.ijo.0802142

Montague CT, Farooqi IS, Whitehead JP, Soos MA, Rau H, Wareham NJ, Sewter CP, Digby JE, Mohammed SN, Hurst JA, Cheetham 
CH, Earley AR, Barnett AH, Prins JB, O'Rahilly S (1997) Congenital leptin deficiency is associated with severe early-onset obesity in humans. Nature 387: 903-908. https://doi.org/10.1038/43185

Morton GJ, Schwartz MW (2011) Leptin and the central nervous system control of glucose metabolism. Physiol Rev 91: 389-411. https:// doi.org/10.1152/physrev.00007.2010

Mottillo S, Filion KB, Genest J, Joseph L, Pilote L, Poirier P, Rinfret S, Schiffrin EL, Eisenberg MJ (2010) The metabolic syndrome and cardiovascular risk a systematic review and meta-analysis. $\mathrm{Am}$ Coll Cardiol 56: 1113-1132. https://doi.org/10.1016/j.jacc.2010.05.03

Mueller WM, Gregoire FM, Stanhope KL, Mobbs CV, Mizuno TM, Warden CH, Stern JS, Havel PJ (1998) Evidence that glucose metabolism regulates leptin secretion from cultured rat adipocytes. Endocrinology 139: 551-558. https://doi.org/10.1210/en.139.2.551

Poslusna K, Ruprich J, de Vries JH, Jakubikova M, van't Veer P (2009) Misreporting of energy and micronutrient intake estimated by food records and 24 hour recalls, control and adjustment methods in practice. Br J Nutr 101 (Suppl 2): S73-S85. https://doi.org/10.1017/ S0007114509990602

Pratley RE, Ren K, Milner MR, Sell SM (2000) Insulin increases leptin mRNA expression in abdominal subcutaneous adipose tissue in humans. Mol Genet Metab 70: 19-26. https://doi.org/10.1006/ mgme.2000.2995

Reseland JE, Haugen F, Hollung K, Solvoll K, Halvorsen B, Brude IR, Nenseter MS, Christiansen EN, Drevon CA (2001) Reduction of leptin gene expression by dietary polyunsaturated fatty acids. J Lipid Res 42: 743-750. PMID: 11352981

Rizzo NS, Sabaté J, Jaceldo-Siegl K, Fraser GE (2011) Vegetarian dietary patterns are associated with a lower risk of metabolic syndrome: the adventist health study 2. Diabetes Care 34: 1225-1227. https://doi.org/10.2337/dc10-1221

Rössner S (2006) Obesity: the disease of the twenty-first century. Int J Obes Relat Metab Disord 26 (Suppl 4:) S2-S4. https://doi. org/10.1038/sj.ijo.0802209

Sabaté J, Wien M (2015) A perspective on vegetarian dietary patterns and risk of metabolic syndrome. Br J Nutr 113 (Suppl 2:) S136S143. https://doi.org/10.1017/S0007114514004139

Sharma V, Mustafa S, Patel N, Wambolt R, Allard MF, McNeill JH (2009) Stimulation of cardiac fatty acid oxidation by leptin is medi- ated by a nitric oxide-p38 MAPK-dependent mechanism. Eur I Pharmacol 617: 113-117. https://doi.org/10.1016/j.ejphar.2009.06.037

Shen W, Wang C, Xia L, Fan C, Dong H, Deckelbaum RJ, Qi K (2014) Epigenetic modification of the leptin promoter in diet-induced obese mice and the effects of $\mathrm{n}-3$ polyunsaturated fatty acids. Sci Rep 4: 5282. https://doi.org/10.1038/srep05282

Shimabukuro M, Koyama K, Chen G, Wang MY, Trieu F, Lee Y, Newgard CB, Unger RH (1997) Direct antidiabetic effect of leptin through triglyceride depletion of tissues. Proc Natl Acad Sci USA 94 : 4637-4641. https://doi.org/10.1073/pnas.94.9.4637

Thompson FE, Byers T (1994) Dietary assessment resource manual. J Nutr 124 (Suppl 11): 2245S-2317S. https://doi.org/10.1093/jn/124. suppl_11.2245s

Tonstad S, Butler T, Yan R, Fraser GE (2009) Type of vegetarian diet, body weight, and prevalence of type 2 diabetes. Diabetes Care 32: 791-796. https://doi.org/10.2337/dc08-1886

Toyoshima Y, Gavrilova O, Yakar S, Jou W, Pack S, Asghar Z, Wheeler MB, LeRoith D (2005) Leptin improves insulin resistance and hyperglycemia in a mouse model of type 2 diabetes. Endocrinology 146: 4024-4035. https://doi.org/10.1210/en.2005-0087

Ukropec J, Reseland JE, Gasperikova D, Demcakova E, Madsen L, Berge RK, Rustan AC, Klimes I, Drevon CA, Sebökova E (2003) The hypotriglyceridemic effect of dietary n-3 FA is associated with increased beta-oxidation and reduced leptin expression. Lipids 38: 1023-1029. https://doi.org/10.1007/s11745-006-1156-z

Van Patten S, Ranginani N, Shefer S, Nguyen LB, Rossetti L, Cohen DE (2001) Impaired biliary lipid secretion in obese Zucker rats: leptin promotes hepatic cholesterol clearance. Am J Physiol Gastrointest Liver Physiol 281: G393-G404.

William WN Jr, Ceddia RB, Curi R (2002) Leptin controls the fate of fatty acids in isolated rat white adipocytes. J Endocrinol 175: 735-744. https://doi.org/10.1677/joe.0.1750735

Winnicki M, Somers VK, Accurso V, Phillips BG, Puato M, Palatini P, Pauletto P (2002) Fish-rich diet, leptin, and body mass. Circulation 106: 289-291. https://doi.org/10.1161/01. CIR.0000025241.01418.4D 